\title{
Diet and functional feeding groups of Chironomidae (Diptera) in the Middle Paraná River floodplain (Argentina)
}

\author{
M. Celeste Galizzi ${ }^{1}$, Florencia Zilli ${ }^{2} \&$ Mercedes Marchese ${ }^{1,2}$ \\ 1. Facultad de Humanidades y Ciencias (FHUC-UNL), Ciudad Universitaria (3000) Santa Fe, Argentina. \\ 2. Instituto Nacional de Limnología (INALI-CONICET-UNL), Ciudad Universitaria (3000) Santa Fe, Argentina. (mmarchese@inali.unl.edu.ar)
}

\begin{abstract}
The gut contents of nine genera of benthic Chironominae and Tanypodinae from the Middle Paraná River floodplain habitats (a lake and a secondary channel) were analyzed to determine their feeding patterns and functional feeding groups. Amorphous detritus, animal and vegetal tissues, and mineral materials (predominantly sand) were observed in the larval guts. Amorphous detritus were the main food item found for Polypedilum (Tripodura) sp., Chironomus gr. decorus sp., Endotribelos sp., Phaenopsectra sp., Cladopelma sp., and Pelomus sp. (Chironominae), while animal tissues (mainly oligochaetes) were the most important food item found for Ablabesmyia (Karelia) sp., Coelotanypus sp., and Procladius sp. (Tanypodinae). Dietary overlap was calculated for all pairs of genera. Within predators, the highest overlap was obtained between Coelotanypus sp. and Ablabesmyia (Karelia) sp., while within detritivores the highest niche overlap was obtained between Endotribelos sp. and Phaenopsectra sp.
\end{abstract}

KEYWORDS. Gut content, niche overlap, Chironominae, Tanypodinae.

\begin{abstract}
Resumen. Dieta y grupos funcionales tróficos de Chironomidae (Diptera) de la llanura aluvial del río Paraná Medio (Argentina). Se analizó el contenido intestinal de nueve géneros de Chironominae y Tanypodinae bentónicos en ambientes de la llanura aluvial del río Paraná Medio (laguna y cauce secundario) para determinar su patrón alimentario y los grupos funcionales tróficos. En los contenidos intestinales se observaron detrito amorfo, material mineral (principalmente arena), tejidos vegetal y animal. El principal ítem alimentario encontrado en Polypedilum (Tripodura) sp., Chironomus gr. decorus sp., Endotribelos sp., Phaenopsectra sp., Cladopelma sp. y Pelomus sp. (Chironominae) fue detrito amorfo, mientras que en Ablabesmyia (Karelia) sp., Coelotanypus sp. y Procladius sp. (Tanypodinae) el ítem más importante fue tejido animal (principalmente restos de oligoquetos). Se calculó el solapamiento trófico entre todos los pares de géneros, obteniéndose el mayor solapamiento dentro de los depredadores entre Coelotanypus sp. y Ablabesmyia (Karelia) sp. y dentro de los detritívoros entre Endotribelos sp. y Phaenopsectra sp.
\end{abstract}

PALABRAS-CLAVE. Contenido intestinal, solapamiento de nichos, Chironominae, Tanypodinae.

The knowledge of the diet offer important information to analyze the ecological role of species in any ecosystem. Interactions between species and with their environment, the life history strategies, and their ecologic role determine the structure of communities, the species diversity, the relative abundance of organisms and resource distribution patterns within systems. In addition, the studies related to biotic interactions give essential information to plan adequate strategies for the management of natural resources. Indeed, the partitioning of resources amongst closely related species as a structuring force for communities has been a central theme in the development of modern ecology (LEIBOLD, 1995; Tokeshi, 1999; Pulliam, 2000; Death, 2004).

Benthic invertebrates are functionally important in the aquatic food webs as they process basal resources that are transferred to the higher trophic levels. Benthic invertebrates were first assigned to FFGs (functional feeding groups) in relation to their feeding mechanisms and the type and size of food they consumed (Cummins, 1973). Therefore, shredders break and condition leaves favouring the colonization of processed detritus by microorganisms and other invertebrates, while scrapers consume algae and microbes attached to the coarse particulate organic matter (CPOM) (MAGEE, 1993). The collector-filterers and collector-gatherers filter the fine and ultrafine particulate organic matter (FPOM, UFPOM) from the water column and directly from the substrate respectively (GRAÇA, 2001). Moreover, predators consume animals or some of their parts.

The structure of benthic invertebrate assemblages may also be analyzed through the degree of niche overlap between species. The niche represents the conditions and resource quality within which an individual or species can reproduce and survive (RICKLEFS, 1998; TOWNSEND Peterson, 2006; Soberón, 2007). Niche overlap occurs when species use the same resources simultaneously and it is used to test the hypothesis of limiting similarity, which states that species with high niche overlap will be unable to coexist (MACARTHUR \& Levins, 1967).

The feeding habits of invertebrates of different Neotropical streams were studied by GRAÇA et al. (2001); Henriques-Olivera et al. (2003); Motta \& Uieda (2004); CuMmins et al. (2005); AlBARIÑo \& DíAZ Villanueva (2006); Gill et al. (2006); Tomanova et al. (2006); Callisto et al. (2001, 2007); SAnseverino \& Nessiminian (2008); Reynaga (2009); Saigo et al. (2009). Furthermore, shredders are important in first-order streams and therefore their diet was widely described by several authors (e.g. PALMER et al., 1993; RosiMarshall \& Wallace, 2002; Cheshire et al., 2005). However, the feeding patterns of the dominant benthic invertebrates in the Paraná River system, like in many other large rivers, are still scarcely known. Therefore, the main objectives of this study were to analyze the diet and to determine the functional feeding group of benthic 
Chironomidae commonly found in floodplain habitats of the Middle Paraná River. Besides, also the niche overlap was calculated for all genera to determine coexistence degree in trophic dimension.

\section{MATERIALS AND METHODS}

Larvae of chironomids were collected between 2002-2005 in the bank of a secondary channel (the Tiradero River) and a floodplain lake $\left(31^{\circ} 40^{\prime} \mathrm{S}-\right.$ $60^{\circ} 33^{\prime} \mathrm{W}$ ) of the Middle Paraná River. The bottom sediment in both habitats was silt-clayed $(44-50 \%$ of clay and $27-44 \%$ of silt) with $2-9 \%$ of bottom organic matter (ZiLLi et al., 2008).

To collect the same number of individuals required to analyze the gut content by species, qualitative samplings were carried out in the floodplain habitats in different periods. Larvae were preserved in $70 \%$ ethanol. The foreguts of 10 individuals per taxa were removed by dissection, mounted in glycerin and examined at 400x magnifications.

The percentage of each food item was obtained by a volumetric method, where the guts of chironomids were approximated to cylinders. The food contained in the guts was assumed as the $100 \%$ and the proportions of the different types of food were estimated using an eyepiece micrometer scale of $10 \times 10$ (CHESHIRE et al., 2005).

The genera were identified following PAGGI (2009), Trivinho-Strixino \& Strixino (1995) and Trivinho-Strixino (2011) and were assigned to the corresponding functional feeding groups (FFGs) based in the dominant food item. These results were compared with the widely used categories of MERRIT \& Cummins (1984). Although Polypedilum (Tripodura) sp., Chironomus gr. decorus sp., Endotribelos sp., Phaenopsectra sp. and Ablabesmyia (Karelia) sp. were collected from the lotic environments and Pelomus sp., Cladopelma sp., Coelotanypus sp., and Procladius sp. from the floodplain lake in the present study, all the genera are common in both habitats.

The Chi-square test $\left(\chi^{2}\right)$ was applied to evaluate significant differences in the diet of the chironomid larvae, considering the relative proportion of each food item for the studied genera.

To assess differences in the feeding patterns among the individuals of each genus similarity analysis were performed by Non-Metric Multidimensional Scaling (NMDS) applying Bray-Curtis dissimilarity with $\log _{10}$ transformed data and ANOSIM, using PRIMER-E® software (version 6.1). In a NMDS a $\leq 0.2$ stress gives a potentially useful picture of the data structure, while a $\leq 0.1$ stress corresponds to a good ordination with no prospect of misleading interpretation (CLARKE \& WARWICK, 2001). Besides, a 2D NMDS plot with $\leq 0.1$ stress indicate that higher-dimensional solutions and increasing quantity of data will not add any additional information about the overall structure.
Niche overlap was calculated using Pianka's Index (Pianka, 1973, 1974), using EcoSim, 7.0 Version (Gotelli \& Entsminger, 2001). This index has been widely used in similar studies of stream invertebrate communities (WoODWARd \& HiLdREW, 2002).

Where $P i j$ and $P i k$ represent the proportions of the $i t h$ item used by the $j t h$ and the $k t h$ genus, respectively. This equation generates a single value of niche overlap between zero (no overlap) and one (complete overlap) for each pairwise comparison.

\section{RESULTS}

The food items registered in the gut content of the detritivorous chironomids (Chironominae) included amorphous detritus and mineral materials (predominantly sand), while the guts contents of the predators (Tanypodinae) also included algae (mainly Bacillariophyceae) and animal tissues (oligochaetes, parts of arthropods, rotifers, etc.). Polypedilum (Tripodura) sp., Chironomus gr. decorus sp., Pelomus sp., Cladopelma sp., Endotribelos sp. and Phaenopsectra sp. fed mainly on amorphous detritus (Fig. 1). Some specimens of Chironomus gr. decorus sp. and Endotribelos sp. showed variations in their diet (Fig. 1). Ablabesmyia (Karelia) sp., Coelotanypus sp. and Procladius sp. fed primarily on animal tissues (mainly oligochaetes) (Fig. 2). Thus, Polypedilum (Tripodura) sp., Chironomus gr. decorus sp., Pelomus sp., Cladopelma sp., Endotribelos sp. and Phaenopsectra sp. were detritivores while Ablabesmyia (Karelia) sp., Coelotanypus sp. and Procladius sp., were predators.

The diet of the chironomids of each genus did not show significant differences $\left(\chi^{2} 16.91, \mathrm{p}>0.05, \mathrm{df}=9\right)$. On the other hand, the dissimilarity among genera was

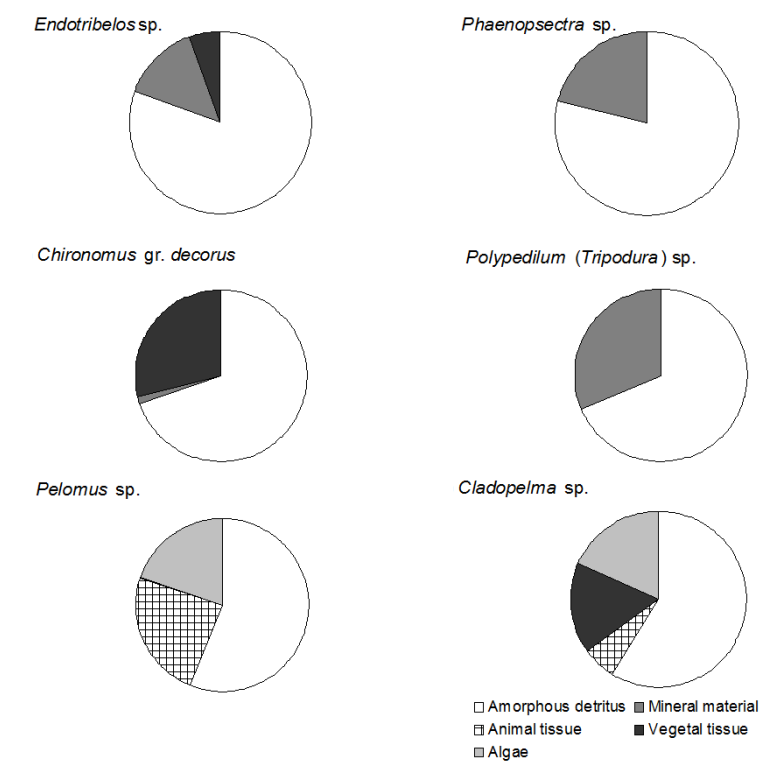

Fig. 1. Food items obtained from the gut content analysis of Endotribelos sp., Phaenopsectra sp., Chironomus gr. decorus sp., Polypedilum (Tripodura) sp., Pelomus sp. and Cladopelma sp. $(\mathrm{n}=10)$ in the Middle Paraná River floodplain during the study period. 
significative (ANOSIM, $\mathrm{R}=0.797, \mathrm{p}=0.001$ ) showing a gradient from Chironomus gr. decorus sp. to Pelomus sp. within detritivores and a higher similarity among the predators (Fig. 3, Tab. I). The stress value obtained for the 2D NMDS plot, indicated that a good ordination was obtained for the overall structure of data corresponding to the diet of chironomids. The highest niche overlap

Coelotanypus sp.

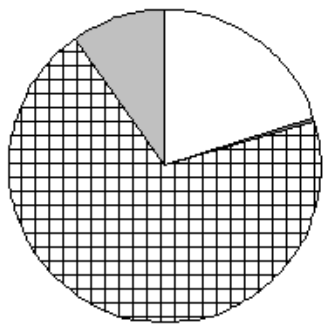

Ablabesmyia (Karelia) sp.

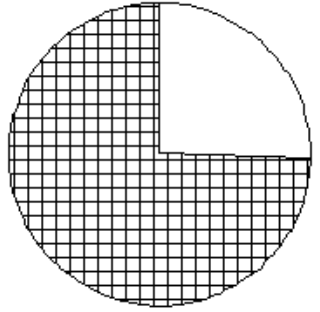

Procladius sp.

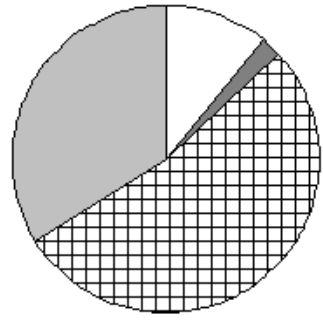

$\begin{array}{ll}\square \text { Amorphous detritus } & \square \text { Mineral material } \\ \boxplus \text { Animal tissue } & \square \text { Vegetal tissue } \\ \square \text { Algae } & \end{array}$

Fig. 2. Food items obtained from the gut content analysis of Coelotanypus sp., Ablabesmyia (Karelia) sp. and Procladius sp. $(\mathrm{n}=10)$ in the Middle Paraná River floodplain during the study period.
(0.98) within the predator guild was obtained between Coelotanypus sp. and Ablabesmyia (Karelia) sp. Furthermore, the highest niche overlap within the detritivores (0.99) was calculated between Endotribelos sp. and Phaenopsectra sp. (Tab. I). Furthermore, a low niche overlap was calculated among the guilds (predators and detritivores). Dietary overlap decreased from Phaenopsectra $>$ Endotribelos $>$ Polypedilum $>$ Ch ironomus $>$ Cladopelma to Pelomus within detritivores and from Ablabesmyia $>$ Coelotanypus to Procladius within predators (Tab. I).

\section{DISCUSSION}

According to our results, most genera of chironomids consumed detritus as part of their diet. Benthic larvae of midges can reach high densities, and may process high amounts of food and remove suspended matter transferring it into the benthic webs (MALMQVist et al., 2001). Polypedilum (Tripodura) sp. and Phaenopsectra $\mathrm{sp}$. use detritus as their main food source in coincidence with results reported by HenRIQUES-Oliveira et al. (2003). On the other hand, MotTA \& UIEDA (2004) suggested that individuals of the same genus acted as predators. Larvae of Ablabesmyia (Karelia) sp., Coelotanypus sp. and Procladius sp. consumed larger proportions of animal tissues and therefore they were categorized as predators in coincidence with MotTA \& Uieda (2004). However, other results showed that Ablabesmyia consumed mainly detritus (Henriques-Oliveira et al., 2003). The differences in the diet of genera may be attributed not only to the existence of different species into the same genus but also to the development of opportunist strategies when resources availability varies.

Larvae of Chironomus gr. decorus sp. and Endotribelos sp. consumed mainly amorphous detritus in coincidence with Henriques-Oliveira et al. (2003) and MotTa \& Uieda (2004). However, in our study we observed that some larvae also consumed vegetal tissues. Additionally, some specimens of Chironomus gr. decorus sp. consumed vegetal tissues corresponding to the coarse fraction and therefore acted as facultative

Tab. I. Values obtained for niche overlap among genera using the Pianka index in the Middle Paraná River floodplain during the study period.

\begin{tabular}{|c|c|c|c|c|c|c|c|c|}
\hline & $\begin{array}{l}\text { Procladius } \\
\text { sp. }\end{array}$ & $\begin{array}{l}\text { Ablabesmyia } \\
\text { sp. }\end{array}$ & $\begin{array}{l}\text { Pelomus } \\
\text { sp. }\end{array}$ & $\begin{array}{l}\text { Cladopelma } \\
\text { sp. }\end{array}$ & $\begin{array}{l}\text { Chironomus } \\
\text { gr. decorus }\end{array}$ & $\begin{array}{c}\text { Endotribelos } \\
\text { sp. }\end{array}$ & $\begin{array}{l}\text { Phaenopsectra } \\
\text { sp. }\end{array}$ & $\begin{array}{c}\text { Polypedilum } \\
\text { (Tripodura) } \\
\text { sp. }\end{array}$ \\
\hline Coelotanypus sp. & 0.83 & 0.98 & 0.59 & 0.37 & 0.30 & 0.27 & 0.26 & 0.24 \\
\hline Procladius sp. & & 0.83 & 0.62 & 0.38 & 0.15 & 0.17 & 0.17 & 0.16 \\
\hline Ablabesmyia sp. & & & 0.64 & 0.39 & 0.30 & 0.32 & 0.32 & 0.30 \\
\hline Pelomus sp. & & & & 0.92 & 0.80 & 0.85 & 0.84 & 0.79 \\
\hline Cladopelma sp. & & & & & 0.94 & 0.92 & 0.89 & 0.84 \\
\hline $\begin{array}{l}\text { Chironomus gr. } \\
\text { decorus }\end{array}$ & & & & & & 0.94 & 0.90 & 0.85 \\
\hline Endotribelos sp. & & & & & & & 0.99 & 0.96 \\
\hline Phaenopsectra sp. & & & & & & & & 0.98 \\
\hline
\end{tabular}




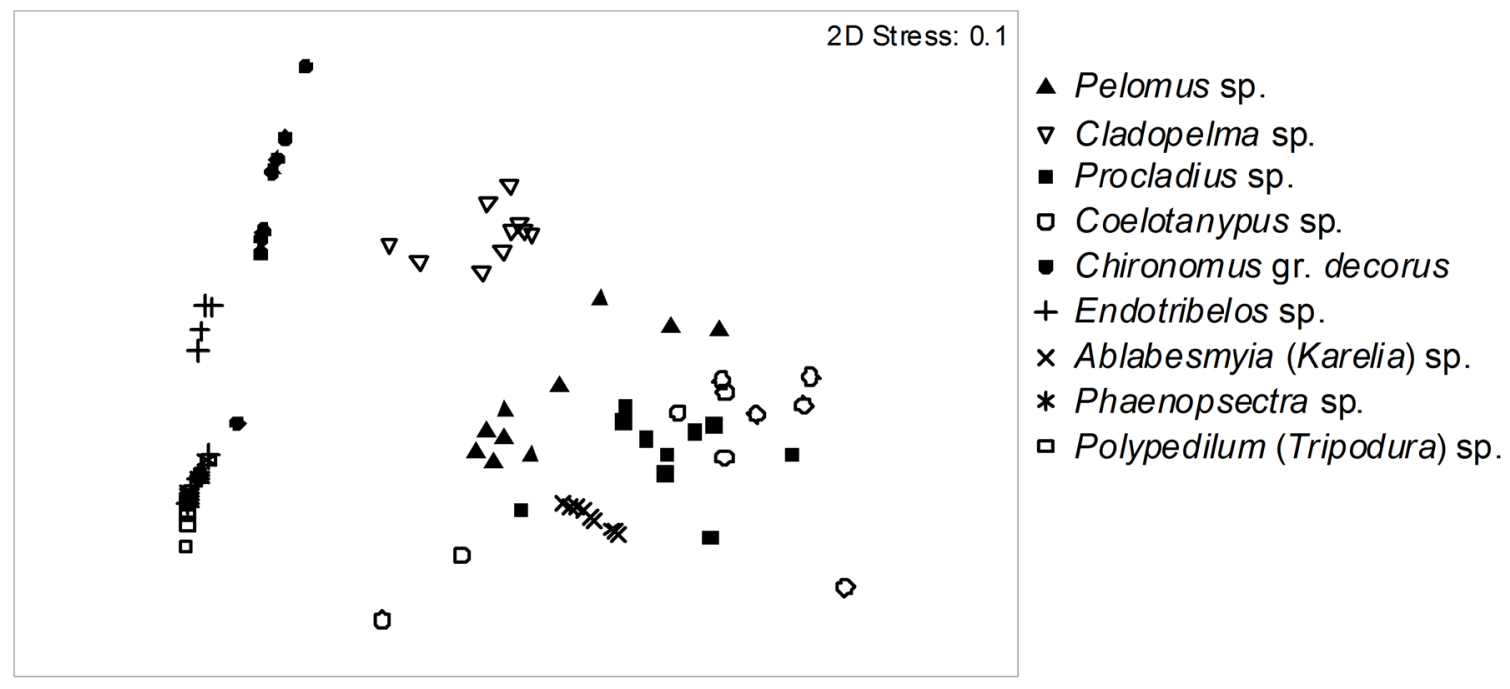

Fig. 3. Plot of non-parametric multidimensional scaling for the proportion of food items in the gut content of chironomids, in the Middle Paraná River floodplain during the study period.

shredders as was suggested by CALListo et al. (2007) and found for the third and fourth instar larvae in floodplain lakes of the Middle Paraná River (Florencia Zilli, unpubl. data). Rosi-Marshall \& Wallace (2002) and Motta \& UIEDA (2004) indicated the importance of FPOM as an unlimited food resource that deeply influence tropical and subtropical aquatic assemblages. According to the results obtained in this study, Polypedilum (Tripodura) sp., Phaenopsectra sp., Chironomus gr. decorus sp., Endotribelos sp. and Pelomus sp. performed as collectorgatherers in coincidence with the classification given by Cummins et al. (2005). However, Chironomus gr. decorus sp. and Endotribelos sp. may also be considered as facultative shredders.

The ANOSIM showed that the proportions of food items in the diet of chironomids are different in coincidence with the results reported by PALMER et al. (1993); Rosi-Marshall \& Wallace (2002); HenriquesOliveira et al. (2003); MotTa \& Uieda (2004); Cheshire et al. (2005); SANSEVERINo \& Nessimian (2008).

Our data revealed high niches overlap among Polypedilum (Tripodura) sp., Phaenopsectra sp., Endotribelos sp., Chironomus gr. decorus sp. and Pelomus sp., mainly in relation to amorphous detritus. Thus, these genera compete for food resources but may coexist in the same habitats because the detritus in floodplain environments of the Middle Paraná River is unlimited. Predators had a lower niche overlap, while the lowest value was obtained for Procladius sp.; thus, in this study the genus showed a better use of the resources. Interspecific competition as results of ecological niches similarity is one of the most important mechanisms organizing and limiting the number of species that participate in an assemblage (JAKSIC \& MARONE, 2007). Several studies have demonstrated that genera reported in the present research commonly coexist in the benthic assemblages of the Middle Paraná River (PoI DE NeIfF
\& Neiff, 1988; Neiff \& Poi de Neiff, 1990; Bruquetas de Zozaya \& Neiff, 1991; Poi de Neiff \& Casco, 2001; Marchese et al., 2002; CAPello et al., 2004; PoI DE NeifF et al., 2006; Montalto \& PagGi, 2006; Zilli et al., 2008). In spite of the consumption of similar food items by genera, the wide availability of resources in natural environments of the Middle Paraná River, allow the development and coexistence of their populations.

Acknowledgments. The authors are grateful for the financial support of the Consejo Nacional de Investigaciones Científicas y Técnicas (CONICET) and the Universidad Nacional del Litoral (UNL).

\section{REFERENCES}

Albariño, R. \& Díaz Villanueva, V. 2006. Feeding Ecology of two Plecopterans in low order Andean - Patagonian streams. International Revue Hydrobiologie 91(2):122-135

Bruquetas de Zozaya, I. \& Neiff, J. J. 1991. Decomposition and colonization by invertebrates of Typha latifolia L. litter in Chaco cattail swamp (Argentina). Aquatic Botany 40:185-193.

Callisto, M.; Gonçalves JR., J. F. \& Graça, M. A. S. 2007. Leaf litter as a possible food source for chironomids (Diptera) in Brazilian and Portuguese headwater streams. Revista Brasileira de Zoologia 24(2):442-448.

Callisto, M.; Moreno, C. E. \& Barbosa, F. A. R. 2001. Habitat diversity and benthic functional trophic groups at Serra do Cipó, southeast Brazil. Revista Brasileira de Biologia 61:259-266.

Capello, S.; Marchese M. \& Escurra de Drago, I. 2004. Descomposición y colonización por invertebrados de hojas de Salix humboldtiana en la llanura aluvial del río Paraná Medio. Amazoniana 18(1/2):125-143.

Cheshire, K; Boyero, L. \& Pearson, R. 2005. Food webs in tropical Australian streams: shredders are not scarce. Freshwater Biology 50:748-769.

Clarke, K. \& Warwick, R. M. 2001. PRIMER-E $®$ software Change in Marine Communities, an approach to statistical analysis and interpretation. Version 6.1. United Kingdom, Plymouth Marine Laboratory.

Cummins, K.W. 1973. Trophic relations of aquatic insects. Annual Review of Entomology 18:183-206.

Cummins, K. W.; Merritt, R. W. \& Andrade, P. C. N. 2005. The use of invertebrate functional groups to characterize ecosystem attributes in selected streams and rivers in south Brazil. Studies on Neotropical Fauna and Environment 40(1):69-89.

Death, R. G. 2004. Patterns of spatial resource use in lotic invertebrate assemblages Hydrobiologia 513:171-182. 
Gill, M.A.; Garelis, P. A. \& Vallania, E. A. 2006. Hábitos alimentarios de larvas de Polycentropus joergenseni Ulmer, 1909 (Trichoptera: Polycentropodidae) en el río Grande (San Luis, Argentina). Gayana 70(2):206-209.

Gotelli, N. J. \& EnTSMinger, G. L. 2001. EcoSim: Null models software for ecology. Version 7.0. Acquired Intelligence Inc. \& Kesey-Bear.

GraçA, M. A. S. 2001. The role of invertebrates on leaf litter decomposition in streams - a Review. International Review of Hydrobiology 86(4-5):383-393.

Graça, M. A. S.; Cressa, S. C.; Gessner, M. O.; Feio, M. J.; Callies, K. A. \& BARRIOS, C. 2001. Food quality, feeding preferences, survival and growth of shredders from temperate and tropical streams. Freshwater Biology 46:947-957.

Henrigues-Oliveira, A. L.; Nessimian, J. L. \& Dorvillé, L. F. M. 2003. Feeding habits of Chironomid larvae (Insecta: Diptera) from a stream in the floresta da Tijuca, Rio de Janeiro, Brazil. Brazilian Journal Biology 63(2):269-281.

JAKSIC, F. M. \& MARONE, L. 2007. Ecología de Comunidades. 2ed. Santiago, Ediciones Universidad Católica de Chile. 336p.

LEIBOLD, M. A. 1995. The niche concept revisited: mechanistic models and community context. Ecology 76:1371-1382.

MacArthur, R. \& LeVINS, R. 1967. The limiting similarity, convergence, and divergence of coexisting species. The American Naturalist 101:377-385

MageE, P. A. 1993. Detrital accumulation and processing in wetlands. Fish and Wildlife Leaflet 13(3):1-7.

Malmovist, B.; Wotton R. S. \& Zhang, Y. X. 2001. Suspension feeders transform massive amounts of seston in large northern rivers. Oikos 92:35-43.

Marchese, M.; Ezcurra de Drago, I. \& Drago, E. 2002. Benthic Macroinvertebrates and Physical Habitat relationships in the Paraná River-floodplain system. In: McClain, M. ed. The Ecohydrology of Southamerican Rivers and Wetlands. International Association of Hydrological Sciences. Special publications n ${ }^{\circ}$ 6. p. 111-131.

Merrit, R. W. \& Cummins, K. W. 1984. An introduction to the aquatic insects of North America. Dubuque, Kendall/Hunt Publishing. 862p.

Montalto, L. \& PaGgi, A. C. 2006. Diversity of chironomid larvae in a marginal fluvial wetland of the Middle Paraná River floodplain, Argentina. Annales de Limnologie 44(2):289-300.

MotTA, R. L. \& UiedA, V. S. 2004. Diet and trophic groups of an aquatic insect community in a tropical stream. Brazilian Journal Biology 64(4):809-817.

NeifF, J. J. \& Poi de NeIfF, A. 1990. Litterfall, leaf decomposition and litter colonization of Tessaria integrifolia (Compositae) in the Paraná River Floodplain. Hydrobiologia 203:45-52.

Paggi, A. C. 2009. Diptera Chironomidae. In: Domínguez, E. \& Fernández, H. eds. Macroinvertebrados bentónicos sudamericanos. Sistemática y Biología. Tucumán, Fundación Miguel Lillo. p. 383-409.

Palmer, C.; O’Keeffe, J.; Palmer, A.; Dunne, T. \& Radloff, S. 1993. Macroinvertebrate functional feeding groups in the midlle and lower reaches of the Buffalo River, Easern Cape, South Africa. I. Dietary variability. Freshwater Biology 29:441-453.
PianKa, E. R. 1973. The structure of lizard communities. Annual Review of Ecology, Evolution, and Systematics 4:53-74.

1974. Niche overlap and diffusion competition. Proceedings of the National Academy of Sciences 71:2141-2145.

Poi de Neiff, A. \& Casco, S. L. 2001. Caída de hojas, descomposición y colonización por invertebrados en palmares de la planicie de inundación del río Paraná (Chaco, Argentina). Interciencia 26(11):567-571.

Poi de NeIFF, A. \& Neiff, J. J. 1988 Decomposition of Eichhornia crassipes in a pond of Paraná River valley and colonization by invertebrates. Tropical Ecology 29(2):79-85

Poi de NeIfF, A; NeIFF, J. J. \& CASCO, S. L. 2006. Leaflitter decomposition in three wetland types of the Paraná River floodplain. Wetlands 26(2):558-566.

Pulliam, H. 2000. On the relationship between niche and distribution. Ecology Letters 3:349-361.

Reynaga, M. C. 2009 Hábitos alimentarios de larvas de Trichoptera (Insecta) de una cuenca subtropical. Ecologia Austral 29(3):207-214

RickLefs, R. 1998. Invitación a la ecología. Editorial Médica Panamericana. España. 692 p.

Rosi-Marshall, E. \& Wallace, B. 2002. Invertebrate food webs along a stream resource gradient. Freshwater Biology 47:129-141.

Saigo, M.; Marchese, M. \& Montalto, L. 2009. Hábitos alimentarios de Hyalella curvispina Shoemaker, 1942 (Amphipoda: Gammaridea) en ambientes leníticos de la llanura aluvial del río Paraná Medio. Natura Neotropicalis 40(1,2):43-59.

Sanseverino, A. M. \& Nessimian, J. L. 2008. The food of larval Chironomidae (Insecta, Diptera) in submerged litter in a forest stream of the Atlantic Forest (Rio de Janeiro, Brazil). Acta Limnologica Brasiliensia 20(1):15-20.

Soberón, J. 2007. Grinellian and Eltonian niches and geographic distributions of species. Ecology letters 10:1-9.

TOKESHI, M. 1999. Species coexistence: Ecological and evolutionary perspectives. Blackwell Science, Oxford. 464p.

Tomanova, S.; Goitia, E. \& Helesic, J. 2006 Trophic levels and functional feeding groups of macroinvertebrates in neotropical streams. Hydrobiologia 556:251-264.

Townsend Peterson, A. 2006. Uses and requirements of ecological niche models and related distributional models. Biodiversity Informatics 3:59-72

Trivinho-Strixino, S. 2011. Larvas de Chironomidae. Guia de Identificação. São Carlos, Universidade Federal de São Carlos. $371 \mathrm{p}$.

Trivinho-Strixino, S. \& Strixino, G. 1995 Larvas de Chironomidae (Diptera) do estado de São Paulo - Guía de identificação e diagnose dos gêneros. São Carlos, Universidade Federal de São Carlos. 229p.

Woodward, G. \& Hildrew, A. G. 2002. Body-size determinants of niche overlap and intraguild predation within a complex food web. Journal of Animal Ecology 71:1063-1074

Zilli, F.; Montalto, L. \& Marchese, M. 2008. Benthic invertebrates diversity patterns and functional feeding groups in the Middle Parana River Floodplain. Limnologica 38(2):159-171 